\title{
The Influence of Accounting and Tax Report in the Accounting Procedures Regarding the Posted Workers the Case of a Romanian Company from Construction Fields
}

\author{
Daniel Rață \\ “Ştefan cel Mare” University of Suceava, România
}

\begin{abstract}
This article aims to highlight, through a critical analysis, the impact of the accounting - taxation relationship on the internal accounting procedures regarding posted workers. Highlighting the impact of the above-mentioned relationship starts from the analysis of financial-accounting indicators of a construction company and ends with the econometric analysis of the influence of the main indicators specific to posting (daily allowance, accommodation and transport) and preferences regarding the rule: fiscal or accounting.
\end{abstract}

\section{KEYWORDS: posting, daily allowance, accounting, tax, accounting procedures}

\section{INTRODUCTION}

In the case of European posting, the wage cost consists of direct costs (remuneration), a category which includes: the remuneration of directly productive workers (construction workers or drivers, for example) calculated for the work performed and which can be identified by work, services provided, etc. (gross salary, bonuses for special working conditions, etc.) or per diem as well as the related contributions to the state budget. Remuneration is indirect if it is paid for the work performed but cannot be identified by works and services, etc. (rewards, staff training costs, labour costs, sanitary materials or protective equipment, for example).

Wage costs regarding postingof workers to the European Union have a varied structure, customized, especially, on the field of activity of eachcompany. Regarding transport companies, for example, costs with posting of workers usually consist of: the employment wage (which may be equal to or higher than the minimum gross wage per economy) and the daily allowance; in the construction sector, the posting of human resources, from the point of view of the structure of costs specific, is represented by: employment salary, daily allowance, meals and/or accommodation costs. All these salary costs generate, in turn, the size of the tax burden that the employer has to bear. Therefore, it is necessary, for each company,to develop its own accounting procedures regarding the establishment of the salary cost, taking into account the specific tax advantages.

For employers witch are posting of workers to the European Union, the decision to establish the remuneration system for the posted workers is strongly influenced by the concern to minimize costs but also by the methods of taxing each component of the remuneration system.

Taxingthe daily allowance, for example, form the basis for determining the remuneration of the posted worker may create distortions as regards compliance with the rules on the minimum wage for the posted worker in the host State.

Financial - accounting information on posting of workers at EU level is engaged in a process of adaptation to current requirements and in the light of the accounting - tax relations. The reality has shown that the system of contributions and taxes has its own dynamics and the accounting and fiscal policies are becoming more and more a reality based on the harmonization of the employer's interests with the social ones, through taxes.

This information are an indispensable information subsystem in the decision-making process, viewed from the perspective of correct expenditure management, the separation of total costs into categories correlated with cost determinants, caused by posting of workers, and in another wording gives management the necessary coherence (Mihai et al., 2012), because it ensures the necessary premises for knowing them at the level of all decision-makers.

Posting of workers accounting is the information system that states the determination of contributions and taxes, and the production of this information is the responsibility of professional accountants (Oprean\&Oprean, 2012).

So, given the development of economic and financial relations and the increase of postings of workers in the European Union, the synchronization of taxation with the accounting of companies which are posting workers, tends to develop an accounting methodology (Dendaw et al., 2016) through which to reduce as much as possible and even eliminate distorted accounting of reality and to express 


\section{of a Romanian Company from Construction Fields"}

fairness in achieving financial-accounting relationships (Feleagă\&Ionașcu, 1998).

\section{Structure ANd Dynamics of PostingCosts}

In the following we will highlight the USS SRL (a company which operate in the field of electrical installations works) management strategy in elaboration of the internal accounting procedures regarding posting of workers so as to make use of the opportunity of the fiscal advantages. The analysis will be based on the comparative calculation of salary costs for the period January 2018 - June 2018, due to the confidential nature of the information. Therefore, the confidentiality of the information had the effect of limiting the comparative analysis for the six months, the period for which USS S.R.L. provided us the accounting information and, therefore, an extension of the quantitative dynamics would provide complex accounting information, with an extended degree of relevance.

Based on the accounting information provided by the economic entity, the statement of salary expenses is reflected in the table no. 1 :

Table no. I. USS S.R.L. Posting costs level

\begin{tabular}{|l|l|}
\hline Indicator & Amount \\
\hline Gross salary expenses (euro) & 18.836 \\
\hline $\begin{array}{l}\text { Other expenditure with posted workers, of } \\
\text { which (euro): }\end{array}$ & 72.297 \\
\hline - Daily allowance & 50.575 \\
\hline - Costs with posted workers transportation & 12.960 \\
\hline - Accommodation expenses & 8.762 \\
\hline Average number of posted workers & 8 \\
\hline $\begin{array}{l}\text { Average gross monthly expenditure / posted } \\
\text { worker (euro) }\end{array}$ & 1.898 \\
\hline $\begin{array}{l}\text { Average daily allowance / employee / day } \\
\text { (euro) }\end{array}$ & 58 \\
\hline
\end{tabular}

Source: accounting information from company accounting department

In the table no. I we see all expenses generate by the process of posting workers in six months. The structure of other expenditure with posted workers it can be seen in the graph no. 1:

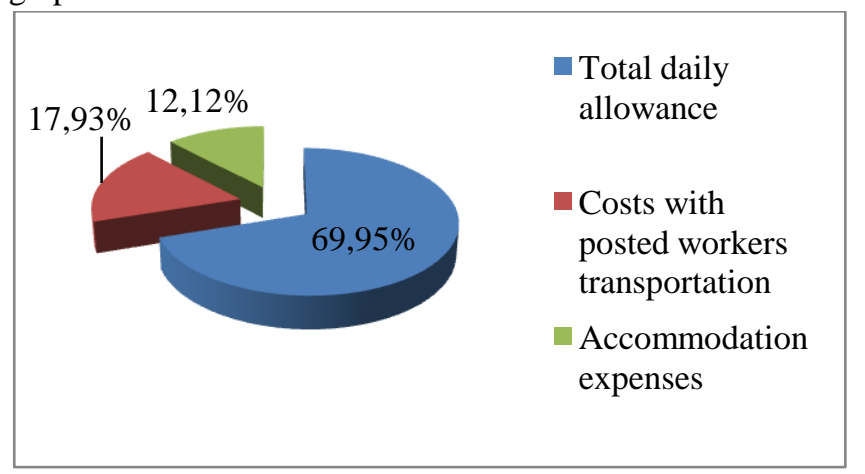

GRAPH NO. 1 THE STRUCTURE OF OTHER EXPENSES GENERATE BY POSTING
If we compare the amount of other expenditure with the total gross salary expenses generate by posting it can be observed that the company have miscellaneous expenses with posting much higher than gross salary expenses $(+283,83 \%)$. Daily allowance has the largest precent in total other expenditure $(69,95 \%)$ while $17,93 \%$ from other expenses are represented by costs with posted workers travel. The lowest level of expenditure is represented by accommodation expensesbut their share is not to be neglected $(12,12 \%)$.

This is because the management choose to pay the posted workers in the form of daily allowance, especially. The questions are: (1) These procedures are in accordance with accounting and tax rules and procedures?, (2) Which are the advantages of such procedures? (3) Why accounting department choose this form of payment (daily allowance bigger than gross salary).

The responses to the above questions can be found in the European regulations, the Romanian legal norms in the field of accounting and taxations and in the cases of European Court.

First, Directive (EU) 2018/957 of the European Parliament and of the Council, amending Directive 96/71/EC concerning the posting of workers in the framework of the provision of services refers to „equal treatment" regarding remuneration. This regulation do not specify what it means the remuneration of the posted workers but refers to exceptions, namely: supplementary occupational retirement pension schemes or allowances or reimbursement of expenditure to cover travel, board and lodging expenses for workers away from home for professional reason. It is mentioned that the daily allowance must be considered part of remuneration only if are paid in reimbursement of expenditure as: travel, board or lodging.However, the case law of the European Court of Justice highlight some elements witch must (can) be considered part of posted workers remunerations, such as: daily travel allowance (Case C - 396/13 Sähköalojen vs ElektrobudowaSpolkaAkcyjna, 2015), payments representing the thirteenth or fourteenth salary - the daily commute to and from work should be longer than one hour (Case C-341/02 Commission v Germany, 2005). In conclusion the payments made as daily allowance are legal and treated as posted workers remuneration. In conclusion, company can pay the posted workers with salary negotiated (in generally is gross minimum wage) and daily allowance. The other cost regarding posting of workers made by company are not considered part of remuneration.

Secondly, daily allowance is treated, from fiscal point of view, by Low no. 227/2015 regarding Tax Code. According Romanian Tax Code maximum 2.5 times the legal level established for the travel allowance, by Government Decision is non-taxable. Amounts in excess of 


\section{of a Romanian Company from Construction Fields"}

this maximum deductible level of the delegation allowance are subject to social security contributions and payroll tax.

The dynamics of the expenditures with gross wages of the economic entity analysed are reflected in the graph no.2:

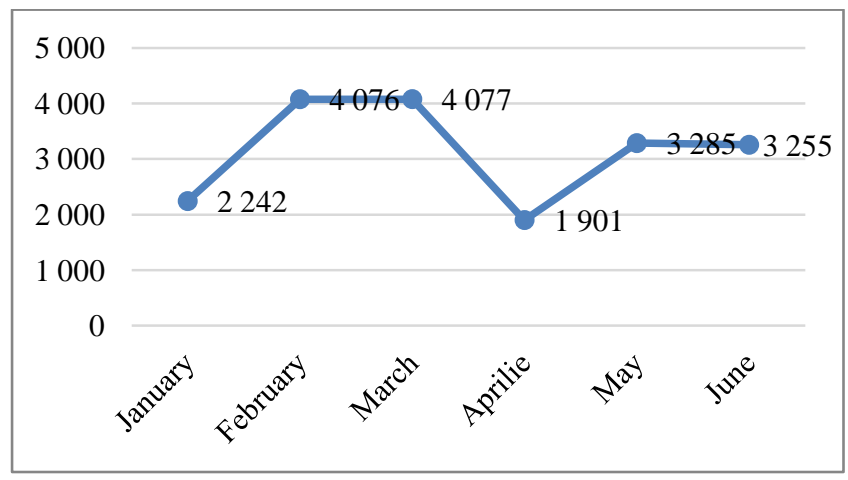

GRAPH NO. 2 THE EVOLUTION OF THE GROSS WAGE PAID

As it can be seen the gross wages has a significant fluctuation from one month to another, a situation created, on the one hand, by the variation of the number of staff, but also by the change of the minimum wage in the economy form February. The increase of the minimum wage in the economy had negative effect: the increase of the wage expenditures by $81.80 \%$ and implicitly the increase of the fiscal burden.

The decrease observed in April is justified by the fact that, in this month, the Easter holidays are celebrated, the employees are no longer postedand their employment contract is suspended. The effect of this accounting procedure consists in decreasing the expenses with the postedworkers but also of the taxes and fees related to the salary.

The daily allowance calculated for seconded staff is reflected inthe graph no. 3 :

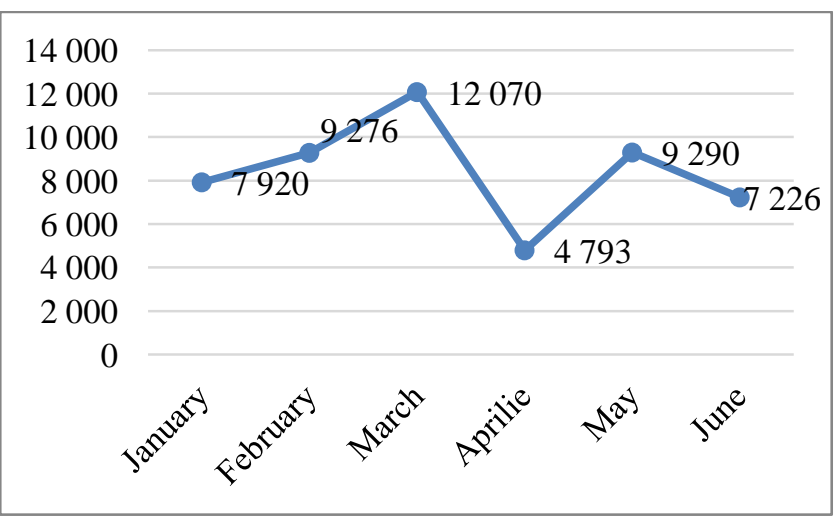

GRAPH NO. 3 ThE EVOLUTION OF THE DAILY Allowance

As it can be observed in the graph no. 3, the daily allowance has the same evolution as the salary paid to posted workers.However, if in the wages situation a significant factor of influence was represented by the change of the minimum wage in the economy, in this situation this factor cannot be taken into account.The changesof the daily allowance can be explained by the change in the number of posted workers but also by the number of days for which they were posted.

Itshould be noted that the average daily allowance level was 58 euros/posted worker/day, the company falling within the interval for which the daily allowance is not taxed (in order for the daily allowance not to be taxed, according to the Romanian legal norms, its value must not exceed 87.5 euro/posted worker/day).

It should be noted that there is a tendency to fall within the deductible tax limit of the daily allowance, which means that the accounting of daily allowance expenses was made on the basis of the tax rule, by pursuing tax advantages by respecting the maximum interval until which company do not have to calculate and pay contributions and taxes to the state budget.

Evolutions of cost with travel and accommodation are reflected in the graphic no. 4 , as follow:

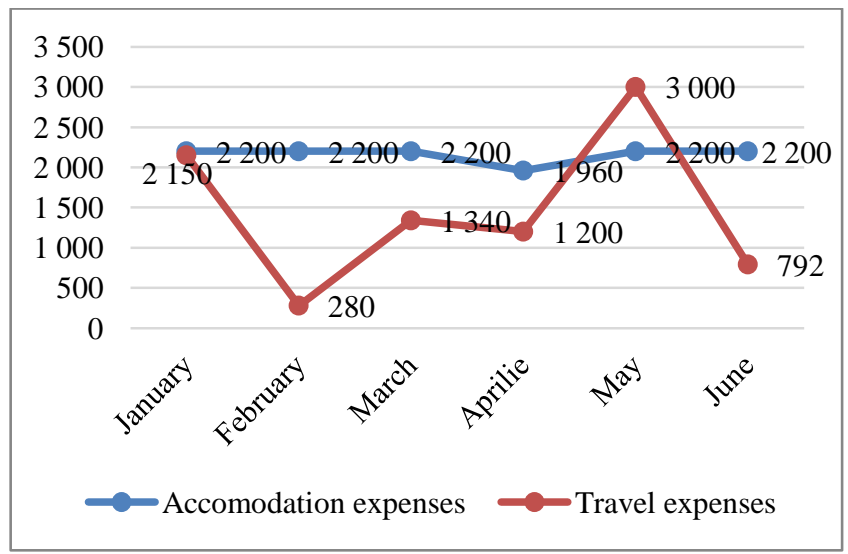

GraPH NO. 4 THE EVOLUTION OF THE ACCOMMODATION EXPENSES AND TRAVEL EXPENSES

If accommodation costs are relatively constant, the same cannot be said about the travel costs of posted workersfrom their place of residence (accommodation) to work and back, where there is a significant oscillation from month to month.

Analysing the accounting information provided bycompany entity, it can be concluded that, in the case presented, in addition to the fact that these costs are diversified in structure, varies significantly from month to month. This requires increased attention that the professional accountant must pay both to the documents underlying the calculation of posting of workers to the European Union and to the calculations made.

Also, the variety of factors that have an impact on the level and dynamics of salary and similar costs in construction companies (weather, staff turnover, number of contracts, etc.) further complicates the task of the professional accountant who must forecast the revenue budget and expenses but also cash flow. 


\section{ANAlysis of THE SENSITIVITy OF COMPANY COSTS} WITH POSTING OF WORKERS

The proposed econometric model to highlight the degree of sensitivity of posting of workers costs to the European Union, at the level of company, in relation to the influencing factors is a nonlinear regression model that is transformed into a linear model by logarithm, and the equation takes the following form:

Information:

$$
\mathrm{Y}_{\mathrm{x} 1}=\mathrm{a}+\propto_{1} \mathrm{Ch}_{\mathrm{D}}+\propto_{2} \mathrm{Ch}_{\mathrm{A}}+\propto_{3} \mathrm{Ch}_{\mathrm{T}}+\mathrm{u}_{\mathrm{t}}
$$

- $\mathrm{Y}_{\mathrm{x} 1}$ - posting costs - the dependent variable;

- a - scale parameter;

Table no. II.Descriptive statistics

\begin{tabular}{|c|c|c|c|c|c|}
\hline Indicator & $\mathbf{N}$ & Minimum & Maximum & Mean & Std. Deviation \\
\hline Posting of workers expenses & 6 & 46.064 & 92.179 & $71.134,167$ & $16.120,150$ \\
\hline Daily allowance & 6 & 22.338 & 56.253 & $39.297,167$ & $11.341,421$ \\
\hline Travel expenses & 6 & 1.305 & 13.982 & $6.807,500$ & $4.550,700$ \\
\hline Accommodation expenses & 6 & 9.135 & 10.273 & $10.070,500$ & 458,365 \\
\hline Fiscal expenses & 6 & 3.835 & 7.812 & $6.007,167$ & $1.740,532$ \\
\hline
\end{tabular}

\section{Source: Output SPSS (2020)}

Theexpenses with the taxes regarding the posted workers represented $8.44 \%$ of the total costs. This percentage is acceptable and is supported by daily allowance, which has been granted at a level below the taxable limit to the addition of accommodation and meals of posted workers.
- $\alpha_{1}-$ coefficient of elasticity of costs with posting of workers in relation to the influencing factor, daily allowance $\left(\mathrm{Ch}_{\mathrm{D}}\right)$;

- $\alpha_{2}$ - coefficient of elasticity of costs with posting of workers in relation to the influencing factor, accommodation expenses $\left(\mathrm{Ch}_{\mathrm{A}}\right)$;

- $\alpha_{3}$ - coefficient of elasticity of costs with posting of workers in relation to the factor influencing travel costs $\left(\mathrm{Ch}_{\mathrm{T}}\right)$.

Table no. II presents the main characteristics of the indicators on which the analysis is based.

Table no. III.Hypothesis testing results

\begin{tabular}{|c|c|c|c|c|c|c|c|}
\hline \multicolumn{8}{|l|}{ Coefficients $^{\mathrm{a}}$} \\
\hline \multirow[b]{2}{*}{ Model } & \multicolumn{2}{|c|}{ Unstandardized Coefficients } & \multirow{2}{*}{\begin{tabular}{|l} 
Standardized \\
Coefficients
\end{tabular}} & \multirow{2}{*}{ t } & \multirow{2}{*}{ Sig. } & \multicolumn{2}{|c|}{$95,0 \%$ Confidence Interval for B } \\
\hline & $\mathrm{B}$ & Std. Error & & & & Lower Bound & Upper Bound \\
\hline \begin{tabular}{|l|l|}
1 & (Constant) \\
\end{tabular} & $-11194,982$ & 32806,221 & &,- 341 & 765 & $-152348,758$ & 129958,794 \\
\hline Ch_diurna & 1,283 &, 147 & ,903 & 8,699 &, 013 &, 648 & 1,917 \\
\hline Ch_cazare & 2,757 & 3,656 &, 078 &, 754 &, 530 & $-12,974$ & 18,488 \\
\hline Ch_transport &, 610 &, 255 &, 172 & 2,391 &, 139 &,- 488 & 1,707 \\
\hline
\end{tabular}

Source: Source: Output SPSS (2020)

Validation of the model as acceptable is the result of applying the Fisher " $F$ " test and the Student " $t$ " test to confirm the percentages of the function:

$-\mathrm{t} \alpha_{1}=8,699>\mathrm{t}_{0,05,2}=2,92$, means that the parameter $\alpha_{1}$ is significantly different from zero, so we can speak of a significant link between the expenses with the posting of workers and those with the daily allowance;

- $\mathrm{t} \alpha_{2}=0,754<\mathrm{t}_{0,05,2}=2,92$, means that the parameter $\alpha_{2}$ is not significantly different from zero, so we cannot speak of a significant link between the expenses with the posted workers and those with accommodation;

- $\mathrm{t} \alpha_{2}=2,391<\mathrm{t}_{0,05,2}=2,92$, means that the parameter $\alpha_{3}$ is not significantly different from zero, so we cannot speak of
The analysis of the accounting and fiscal information was performed for a period of 6 months and the results of econometric model (table no. III) highlight the next theoretical linear fit equation:

$\mathrm{Y}_{\mathrm{x} 1}=-11.194,98+1,28 \times \mathrm{Ch}_{\mathrm{D}}+2,76 \times \mathrm{Ch}_{\mathrm{A}}-+0,61 \times \mathrm{Ch}_{\mathrm{T}}+\mathrm{u}_{\mathrm{t}}$ a significant link between the expenses with the posted workers and those with the travel.

It is observed that the value of the correlation ratio is significantly different from zero $(\mathrm{R}=0.995)$, which denotes a direct and strong connection between the components of the model. This can also be seen from the fact that $\mathrm{F}_{\text {calculated }}>$ $\mathrm{F}_{0.05 .2}(64.681>9.55)$ and Sig. F calculated in table no. III is less than 0.05 , which shows that there is a link between the amount of posting costs and the amount of allowances, respectively accommodation and travel costs. The verification of the veracity of the multifactor regression model and of the multiple correlation ratio based on the Fisher criterion leads to the conclusion that this model is valid, with a significance threshold of 0.05 . 


\section{of a Romanian Company from Construction Fields"}

Parameter values have the following meanings:

- At a modification of the daily allowance expenses by 1 u.m., the expenses with the posted workers will increase by a monthly average of 1,283 u.m.;

- For the factors accommodation expenses and travel expenses, econometric evaluations cannot be made because its parameters are insignificant.

The results of the proposed econometric model highlight the importance of allowance costs for company that posting of workers.

We also emphasize the importance of establishing these costs (with daily allowance) according to the fiscal rule because they represent the largest share in total expenses, respectively $55.49 \%$ and have a significant influence on their dynamics.

\section{THE INFLUENCE OF ACCOUNTING AND TAX REPORT ON Accounting Procedures Regarding Posting}

In the absence of clear fiscal regulations, another accounting procedure regarding the mobility of human resources is the one proposed by the control public administrations (Hlaciuc\&Rață, 2019), namely: reconsideration of daily allowances as net salaries. Starting from this principle, we will calculate the level of total expenditures related to the mobility of human resources, as well as the size of the fiscal burden that would have been due in this situation (graph no. 5).

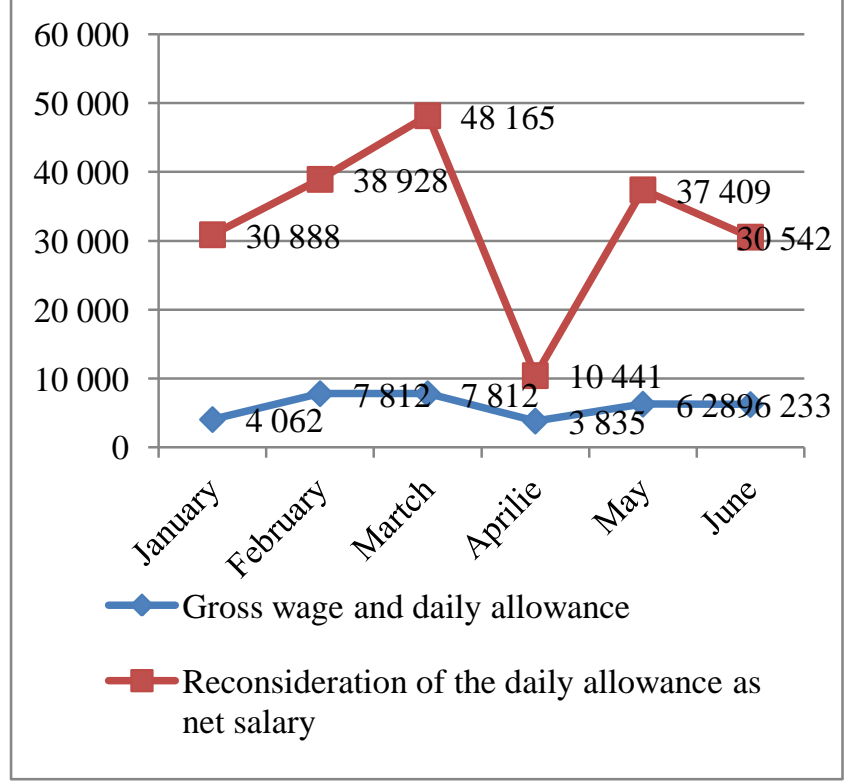

GRAPH NO. 5THE LEVEL AND DYNAMICS OF THE TAX BURDEN DEPENDING ON THE ACCOUNTING PROCEDURES APPLIED

If we analyse the graph no. 5it can strongly state that taxation has a significant influence on accounting information, the influence of the accounting-taxation relationship, being fully felt on the accounting procedures regarding the mobility of human resources. In the institution proposed by the control bodies of the public administration, the level of the fiscal burden is, on average, 5 times higher than in the situation that is found in practice. These increases of the tax burden will later be found in the level of posting costs and, implicitly, will affect the company profitability, if not, even business continuity. The data provided by the company capture a significant influence of the accounting - taxation relationship on the accounting procedures in the analysed period, especially in the absence of a legislative framework to clarify what is the accounting procedure in the situation of posting of worker. The fiscal effect of the tax burden (tax rates on pensions and health budgets, income tax on wages and insurance contribution) identified by analysing the two accounting procedures that can be found in the company can be estimated as significant.

According to the entity's financial policy, the main objectives set are: achieving an optimal financial structure, increasing profitability, identifying and using tax facilities, all of which result in increasing the value of the analysed company. In order for accounting procedures related to the mobility of human resources to be carried out efficiently, the company has developed a series of accounting and fiscal policies, obviously influenced by the accounting-tax relationship, as can be seen from the accounting and fiscal information provided by entity, at our disposal.

Through these fiscal policies, the entity has adopted a series of accounting rules so as to meet both the need for information (record of daily allowance, travel and accommodation, dispatch, per individual worker, for example) and the legal requirements imposed by various relevant legislation (application or non-application of options that tax regulations allow them to use - granting a daily allowance below the taxable ceiling, remuneration of the posted workers with a salary to which to add the daily allowance or treating the allowance as such, for example). However, we believe that taxation should not intervene in accounting, any discrepancy between accounting and tax policies should be resolved extra-accounting.

\section{CONCLUSION}

It is noted, in this context, that the company is subject to fiscal pressures due to the uncertainty caused by the lack of clear rules regarding posting workers. Theaccountingtaxation relationship and its influence on accounting procedures in terms of posting of workers must be viewed in terms of „stress relief”, in the case of the analysed company, in the representation of transactions generated by posting, the tax rule is preferred and not the accounting rule, which apparently distorts the reality of this transaction.

This is the most efficient accounting procedure for the company and in support of the fact that such a procedure does not distort the reality of the relevant transactions, we bring the cases of the European Court of Justice which considers daily allowance as part of wage (Hlaciuc\&Rață, 2018) and, in addition to these decisions of the Court, the 
"The Influence of Accounting and Tax Report in the Accounting Procedures Regarding the Posted Workers the Case of a Romanian Company from Construction Fields"

rules of the Fiscal Code, which considers the daily allowance non-taxable up to a certain ceiling. Consciously, by applying this accounting procedure, the company makes use of the fiscal facilities offered by the Romanian state and achieves its objectives, namely increasing the profitability of economic activity and reducing the tax burden, especially since, through the econometric models used we highlighted the significant influence that daily allowance expenditures have on total human resource mobility costs.

\section{REFERECES}

1. Case C-341/02 Commission v Germany, EU: C: 2005: 220, Judgment of the European Court of 14 April 2005, Case law 2005.

2. Case C - 396/13 Sähköalojen v Elektrobudowa Spolka Akcyjna [2015], ECLI: EU: C - 2015: 86, Judgment of the European Court of 12 February 2015, Case law 2015.

3. Dendaw C., Dupont D., Etienne St., et al. 2016. Le noveau droit comptable belge. Les surprises de la transposition de la Directive 2013/34/UE. Editura Wolters Kluwer, Belgia.

4. Directive (EU) 2018/957 of the European Parliament and of the Council of 28 June 2018 amending Directive 96/71 / EC on the posting of workers in the framework of the provision of services published in the Official Journal of the European Union L173 / 16 of 28 June 2018.

5. Feleagă,N.Ionaşcu, I. 1998. Tratat de contabilitate financiară, vol. II - Ingineria contabilităţii financiare, Editura E conomică, București;
6. Hlaciuc, E. Rață, D. (2018).Comparative analisys of Romanian and EU legislative framework regarding european mobility of workers,European Journal Of Accounting, Finance \& Business, nr. 16, available online at http://www.accountingmanagement.ro/index.php?pag=showcontent\&issu $\mathrm{e}=16 \&$ yea $\mathrm{r}=2018$.

7. Hlaciuc, E. Rață, D.2019,Measuring the impact of fiscal policy of posting from Romania to European Union, The USV Annals of Economics and Public Administration, vol. 19, nr. 1(29), The $15^{\text {th }}$ Economic International Conference, Suceava, available online at

http://www.annals.seap.usv.ro/index.php/annals/ar ticle/view/1147/958

8. Law 227/2015 Fiscal Code, published in the Official Journal of Romania no. 688 of September 10, 2015.

9. Mihai, M. Drăgan, C. Ciumag, M. 2012. Studiu privind îmbunătățirea gestionării informațiilor contabile aferente cheltuielilor cu activitățile desfășurate în UE prin agent de muncă temporară, Financial Audit Magazine, no. 10, pp. 47 - 52

10. Oprean, V. B. \&Oprean D. (2012). Dileme ale inginerieiorganizațiilor:

complementaritatearelațiilorcontabilitate fiscalitateîncontext macro și microeconomic. Journal of Public Finance and Accounting.No. 10, pp. $20-31$. 